SlavVaria 1/2021. 191-201

DOI: $10.15170 /$ SV.1/2021.191

\author{
СОЊА СТОЈМЕНСКА-ЕЛЗЕСЕР \\ (Скопје, Северна Македонија)
}

\title{
Библиски алузии во современиот македонски роман
}

Анотација: Сите словенски книжевности во своите традиции на различни начини, со варијабилен интензитет и зависно од општествениот историски контекст, континуирано го негувале и го негуваат односот кон библискиот текст. Навраќањата кон Библијата во македонскиот современ роман бележат различна динамика и интензитет. Овој труд ги нотира нијансите на интертекстуален однос со Библијата, и тоа: директна цитатност, користење на наслови и ликови, пре-раскажување на библиски приказни (Роман за Ное од Данило Коцевски), целосни реинтерпретации во нов контекст (Ha пат кон Дамаск: загубеното послание до Македонците од Елизабета Баковска) и иронично-пародични преработки (Пророкот од Дискантрија од Драги Михајловски и Вештица од Венко Андоновски.

Клучни зборови: Библија, алузија, интертекст, македонски современ роман

Ако сакаме да ги посочиме книжевните дела кои претставуваат семиотички изворишен систем од кој се напојува христијанско-јудејската култура, па и пошироко, културата воопшто, тогаш секако на прво место, без размислување, би ја посочиле Библијата. И самата создадена како интертекст во однос на она што на духовен план ѝ претходело, таа, „светата книга“ за религиозните, во сферата на т. н. „книжевна република““1 претставува извориште на теми, мотиви, постапки, стилски решенија; со еден збор - нуклеус за понатамошни интертекстуални креативни надоврзувања и испреплетувања. Има многу вистина во ставот на Нортроп Фрај, дека „англиската книжевност не може да ја разбере човек што не ја познава Библијата“ (FRYE 1982), а истиов став ни малку не би изгубил во компетентноста ако се прошири и на сета светска книжевност, и ако се рече дека во проучување на книжевноста не може да се тргне без багажот на библискиот код. Сите словенски книжевности во своите традиции на различни начини, со варијабилен интензитет и зависно од општествениот историски контекст, континуирано го негувале и го негуваат односот кон библискиот текст. И во македонската наука за

\footnotetext{
${ }^{1}$ Оваа синтагма е употребена онака, како што ја сфаќа компаратистката Паскале Казанова во својата книга Светска книжевна република.
} 
книжевност оваа опсервација е многупати потврдена, како на пример, во искажувањето дека: „... идентитетот на современата македонска книжевност почива и врз библиските мотиви и теми, и како таков, бележи непрекинат континуитет. Таа опстојува и кореспондира и преку библиските мотиви со модерните и со постмодерните европски и светски книжевно-уметнички текови, каде што е забележително отсуството на теоцентричниот дискурс, но не и на сакралниот код како вечно тежнение на уметникот кон возвишена стварност“ (ГРАНДАКОВСКА: URL).

Навраќањата кон Библијата во македонскиот современ роман бележат различна динамика и интензитет. Во периодот на социјалистичкото општество, кога и се оформува модерниот македонски роман со сите неопходни атрибути, реферирањето на библиските текстови е речиси незабележително и во ретките случаи каде што постои, тоа е во подзаскриена форма, индиректно и алузивно во класична смисла на зборот. Имено, најчесто во македонските романи од втората половина на дваесеттиот век односот кон Библијата е во форма на алузии на ликови, параболи и симболи од библискиот семиотички комплекс. Библиските алузии во поезијата се многу пофреквентни отколку во прозата.

Најексплицитен пример од тој период е романот Црно семе (1966) од Ташко Георгиевски во кој се појавува лик што го носи името Христос. Овој лик евидентно за прототип го има замислениот Исус според тоа како е насликан во романот. Тој сепак во развојот на дејствието се претвора токму во антипод, противник на религијата, затоа што од разочарување ги ископува очите на светците во црквата. Овој лик-цитат од Библијата во мигот на појавата на романот предизвикал контроверзи затоа што вклучувањето на еден библиски лик во револуцијата било неприфатливо за општествената клима од тие години.

Во оваа примарна група на библиски интертекст може да се вброи и фингираната директна библиска цитатност, односно случајот кога измислените нови ликови говорат познати сентенции од Светото писмо. Такви случаи се забележуваат во романите Кучешко распетие на Славко Јаневски, Пиреј од Петре М. Андреевски, во Фрески и гротески на Венко Андоновски и во многу други книжевни дела.

Со менувањето на односот кон религијата во општеството се менува и статусот на библизмите во македонската книжевност. Религијата во новонастанатиот постсоцијалистички период веќе не е непожелна и маргинализирана тема, туку за неа слободно се дебатира и таа неминовно има специфично влијание и врз кретивните остварувања и на религиозните и на атеистите-автори. Од деведесеттите наваму, во духот на постмодерната поетика, библиските теми и мотиви сѐ почесто се среќаваат во македонските романи, и тоа во различни модуси. Алузиите добиваат спектар од нијанси и се разликуваат и по обем и по сугестивност. Свеста за постмодерната поетика на интертекстуалност ги поттикнува македонските писатели слободно да ги употребуваат 
востановените семантички кодови на Библијата и да ги подвргнуваат на најразлични сопствени креативни стратегии. Веќе не станува збор за алузии единствено во класична смисла на зборот, туку за интертекстуални поврзувања со Библијата кои подразбираат широк спектар на прозни постапки. Употребата токму на определбата „алузии“ во овој контекст е поврзана со изворното значење на коренот на овој збор кој се темели на латинското alludere, односно поигрување. Значи, на ова место не се стремиме да направиме попис на реферирања на библиски теми и мотиви во македонската книжевност, туку би сакале да се фокусираме на начините на кои во македонските современи романи писателите си поигруваат со знаковниот систем, односно книжевниот корпус на Библијата.

Најелементарниот и наједноставен начин на реферирање на Библијата е спомнување на одредени ликови, симболи или параболи во нова контекстуализација. Особено впечатливо е кога одредени синтагми извлечени од контекстот на Библиските приказни се поставуваат во функција на симболи кои се однесуваат на некои нови приказни. Интересен пример за такви реферирања се употребените библизми како наслови на одделни романи, како на пример Адамовото ребро (1999) на Оливера Николова или на романот Пасија по Матеј (2008) од Христо Крстевски.

Повисок степен на однос кон библиските теми и мотиви претставува нивното повторно раскажување, односно пре-раскажување, со современи конотации. т. н. “пре-пишување“ (во англискиот јазик познато како rewriting) е парадигматична стратегија на постмодерните автори. Еден таков пример во македонскиот современ роман претставува Роман за Ное од Данило Коцевски. Тоа е парафраза на апокалиптичната приказна за потопот и Ноевата арка, но во оваа нова македонска верзија посебно е апострофирана една димензија на оваа приказна - стравот од соочувањето со катаклизмата и проблематиката на гревот и казната. Затоа, како поднаслов во заграда на овој роман е испишана неговата основна преокупација - страв. Романот започнува и завршува со директни цитати од Светото писмо, преку кои се проследени родословот на патријарсите од Адама до Ноја и родословот на народите. Низ петнаесетте глави од романот подробно се пре-раскажани основните епизоди од библиската приказна за потопот, но не само таа - низ дијалозите на главните ликови се испреплетуваат и евоцираат и епизодата за постанокот, за Адам и Ева, за братоубиството меѓу Авел и Каин и други епизоди главно од Книгата за постанокот. Прозата на Коцевски во својот ритам и интонација целосно ја имитира библиската приказна и ги користи добропознатите клишеа на библискиот стил, со многу набројувања, повторувања, дијалози и редења на настани, а сите тие се вклопени во еден вообичаен наративен тек, кој си има основни етапи на воведување, развој на основното дејство и кулминација, како и расплет и завршница. Познато е дека Библијата е 
сочинета од жанровски разнородни составки, а во романескната структура на романот на Коцевски различни фрагменти од нив се нивелираат во компилациската прозна целина, која многу често е испресечена со директни цитати, но исто така претрпува и извесни интервенции од авторот, кои отскокнуваат од библиската предлошка. Авторот ги гради ликовите живо и впечатливо, а особено пластично го развива ликот на Хам, многупати определен како „лукавиот“ Хам, кому таткото му го одзема правото на првородството поради непослушноста, грешникот кој ја видел голотијата на татка си и затоа бил проколнат. Токму преку ликот на Хам се збиднува и продорот на апокрифната размисла во романот, кој на прв поглед се чини дека претставува само едноставна варијација на добро познатите теолошки цврсто канонизирани толкувања. Хам ги изговара следните зборови: „Јас ништо не објаснувам, само прашувам“ (КОЦЕВСКИ 2003: 49) за подоцна да продолжи: „Еднаш страдавме поради сопствената грешка, во истиот тој Едем, а сега, со потопот, ќе страдаме по втор пат, поради каењето и грешката Господова. Страдањата наши ќе имаат ли крај? Не верувам дека во потопот едни ќе страдаат праведно, а другите праведно ќе се спасат. Смешно. Јас верувам во Господа, но дали ние добро сме ги разбрале пораката и заканата негова? Праведно ли е мнозинството да страда, или Господ поинаку ќе постапи? Потопот само што не настапил, и јас барам оправдување за страдањето. Исто како и вие. Страдање, страв, и страдање“ (КОЦЕВСКИ 2003: 52). Доминантната скепса кон религиозната догма се манифестира во Хамовата желба „постојано и постојано да се каснува од дрвото на познанието“ (КОЦЕВСКИ 2003: 119), како и во суптилно иронизираната сцена на пронаоѓањето на пијаниот разголен татко на подот од тремот: „’Пијаниот татко Ное, пијаниот татко Ное'- рече Хам, не можејќи да се изначуди. 'Ете, и Господ понекогаш се поигрува со праведниците'. Хам започна да се смее, обидувајќи се да го поткрене татка си. ’Ти реков дека не ти туку јас требаше да пробам од грозјето, новиот плод на познанието, од дрвото на животот', рече Хам, 'а вака, еве што се случи. Но, ми се чини дека ова е некое друго дрво. Дрво на бессознание', зборуваше тој без престан смеејќи се. 'И да е така, ништо не смее да нѐ спречи да го пробаме. Добро е што го проба, татко мој. Добро е. Конечно си на моја страна. Сиот си утоп. Господ ни ја даде довербата да ја владееме земјата и сѐ што има на неа. Како ќе ја владееме, ако сите нешта не ги запознаеме до крај?’“ (КОЦЕВСКИ 2003: 152) Со полифоничниот дискурс Коцевски ја разбива монолитноста на библискиот дискурс и ја осовременува, отворајќи го за пораки и прашања кои се однесуваат на современиот свет, живот и човек. На тој начин тој создава еден специфичен митопоетски роман, отворен кон различни контекстуализации, во кој се остварува конвертирање на алузивноста, наместо тој да алудира на библиската приказна, тој е испишан како библиска приказна која алудира на современата стварност. Креативната репетиција на библиската приказна 
кај Коцевски произведува нови значења и ревизија на мисловната парадигма што е содржана во библискиот текст. Тоа е еден од најфреквентните и типично постмодернистички модели на интертекстуална книжевна стратегија.

Малку поразличен, а сепак мошне близок модел на библиска интертекстуалност се забележува во романот на Елизабета Баковска $\mathrm{Ha}$ пат кон Дамаск: загубеното послание до Македонците (2006). Повторно се среќаваме со симболична фраза „на пат кон Дамаск“ која упатува на библиската приказна за преобраќањето, односно покрстувањето на Савле во христијански проповедник Павле, но во овој случај не се останува само на тоа, туку стратегијата се проширува на целосна реинтерпретација на приказната за Павле и нејзино инкорпорирање во нарацијата на современа тема, прецизно поставена во Македонија во почетокот на третиот милениум и концентрирана врз актуелната политичка ситуација. Романот на Баковска е двоплански, односно составен од две приказни што се упатени една на друга во алузивни споеви. Едната приказна ја реконструира животната врвица на Павле, односно преобратениот Савле, кој во Новиот завет е познат како испраќач на неколку посланија преку кои се проповеда христијанството во различни средини. Веројатно првичен импулс за ова навраќање кон новозаветните посланија е фактот што токму во нив се среќава и топонимот Македонија и одредницата Македонци, така што во овој случај библискиот интертекст добива јасна национална боја, дури може да се рече дека е употребен во функција на потенцирање на националната идеја. Вториот слој на приказната, пак, ја следи судбината на едно младо момче кое е вовлечено во вителот на воените судири во тетовскиот регион во текот на 2001 година во Македонија. Во поигрувањето со библиската приказна Баковска вклучува и доза на мистификаторство испишувајќи низ нарацијата своевидно послание на Павле до Македонците (кое, впрочем, во самиот поднаслов на романот ќе го определи како „загубено“). Двете линии на нарација, од една страна стариот изнемошетен Павле кој во десет глави ја раскажува својата приказна пишувајќи послание до Македонците, и од друга страна, рекапитулацијата на животниот пат на еден млад Македонец, кој е ранет во престрелките во тетовско, се спојуваат во финалето на романот, во кое се случува средба на овие два книжевни лика како сплескување на временските дистанци во едно време и едно место, во една вонвременска завеана во снег планинска колиба, во една вечност, во една смрт. Поврзувањето со библиската предлошка на авторката ѝ послужила да конструира роман кој е посветен на конкретната општествено- политичка ситуација и на личната драма на една индивидуа вплетена во неа, а во исто време токму преку библискиот интертекст, претендира на една митска димензија и на национална самоглорификација. Со особено внимание и продлабочено познавање на библискиот текст во овој роман е изграден ликот на старецот Павле: „Иако веќе со години им пишуваше на 
Римјаните, на Коринтјаните, на Галатјаните, на христијаните во Ефес, на Колос, а еве и на Македонците, секогаш пишувајќи многу и за себе, неговиот живот по оној пат кон Дамаск, всушност, можеше и многу просто да се смести во неколку реченици“ (БАКОВСКА 2006: 94). Сепак, авторката преку реминисценции и навраќања успева прилично детализирано да ги преработи библиските епизоди во еден современ и лесно и угодно читлив текст. Најголем сегмент од приказната за Павле се всушност неговите обраќања кон Македонците: „Вие, Македонци, сте повикани да му припаднете нему, зашто вие сте му мили на Бога и тој ве повика да бидете негов свет народ. Бог, нашиот татко и Господ Исус Христос, ви се благонаклонети и ви даваат вера што како факел ве води низ премрежињата на овој световен живот“ (БАКОВСКА 2006: 8). Како контраст на оваа „божја милост“ за Македонците прозвучува описот на воените дејствија во планинските масиви во западна Македонија, во кои еден куршум го застрелува главниот јунак на современата приказна. Тој при средбата со фантастичниот лик на севременскиот Павле ги изустува следните зборови: „’Татко...' залипа оној до зидот. 'Зошто сето ова ни се случува? Чии гревови плаќаме? Згрешивме ли сите?“ (БАКОВСКА 2006: 162). Творечката игра на Баковска во романот На пат кон Дамаск комбинира повеќе препознатливи постапки, и тоа: симболична употреба на приказната за патот и просветлувањето на Савле, директни цитати од библискиот текст, мистификација во однос на библискиот текст, инклузија на познатите приказни во новата наративна структура која во еден миг буквално се преклопува со преземената библиска приказна... Во овој роман не е јасно дали религиозноста е само фингирана или е примарна определба. Станува збор за писмо кое донесува религиозна опсервација без да интервенира врз неа, ниту ја пародира, ниту ја подведува под знак прашалник.

Наспроти ваквата афирмативна религиозност на дискурсот, во македонската прозна традиција постои силна линија на негување на еретичка запрашаност пред црковните догми, која ги влече своите корени од богомилството, карактеристично за овие простори. Како посебен модел на романи со библиска интертекстуалност се издвојуваат романи кои носат еретичка богомилска атмосфера и кои ги поставуваат на проба постулатите на библиските догми. Тоа се романи кои се однесуваат иронично, пародично или со еден збор апокрифно кон библиските предлошки. Нивниот лудизам не е само на формално ниво, туку станува збор за игра со теоцентричната идеологија и воопшто, игра за потрага по вистината. Во една студија романсиерот Венко Андоновски од позиција на книжевен научник резимира: „По 1945 година, кога македонската култура ги стекнува сите регуларни културни атрибути, меѓу кои и нормираниот литературен јазик, сѐ е подготвено за да се започне со авантурата 'роман'. Но, сѐ случува една интересна културна конверзија: на местото од црковната догма доаѓ социјалистичкиот реализам, додека 
местото на богомилската дисидентска книжевност го преземаат модернистите и подоцна, постмодерните писатели. На тој начин, Библијата и нејзините негации стануваат централен извор кој клучно влијае врз конституцијата на регуларната морфологија на наративните текстови“ (АНДОНОВСКИ 2010: 169). Многу често романите кои се занимаваат со скепсата за постоењето на Бога и за корените на злото (впрочем, за богомилскиот дуализам) се лоцираат во религиозна (црковна, монашка) атмосфера, а во својот тек се развиваат субверзивно кон неа.

Еден таков роман е Пророкот од Дискантрија (2001) од Драги Михајловски. Библискиот интертекст во овој роман претставува специфична „травестија од пародиски вид“ (АНДОНОВСКИ 2010: 168). Романот преку расказот на богомилскиот пророк Василиј Нежил ја актуализира богомилската ерес и ја поврзува со актуелната политичка ситуација во Македонија. Објаснувајќи го богомилството, авторот неминовно реферира и на библиските приказни: „Ако бог е добар, како тогаш ќе ги објасниме злата што се случувале, што се случуваат и ќе се случуваат на земјата? Се согласувам дека бог не прави лошо но тоа не значи дека ова не постои. (...) 'Сакаш да кажеш дека Адам и Ева не ги создал бог? се пеплоса ти и видов како ретката црна коса ти се накостреши до пресно варосаниот таван. 'Бог им го вдахнал духот а телата им ги создал Сатанаил!' испалив ко од пушка. 'Затоа тие се најмногу подложни на грев и зло!““ (МИХАЈЛОВСКИ 2001: 62,63). Реферирањето на Библијата во овој роман најсилно се чувствува во описот на „чудата“ што ги изведува Василиј заради кои подоцна ќе биде прогласен за пророк. Се работи за добро познатите епизоди на чуда што ги изведува Исус во библиските списи (бечвите се полнат со вино, детето се лекува од треска, одење по површината на езерото), но во романот на Михајловски тие се разобличени како измами, кои намерно ги изведува Василиј за доброто на народот и за зголемување на довербата во него. Ова разобличување носи доза на пародичност и хуморност насочени кон светите списи, така што романот има субверзивен карактер во однос на религиозната рамка на библискиот текст. Како историографска метафикција овој постмодернистички роман целосно е свртен кон актуелните проблеми на македонската опстојба, прием во Европска унија, проблеми со јужниот сосед Грција, партизацијата на општеството итн. и сето тоа е фигуративно раскажано преку симболи, алузии и параболи, меѓу кои со посебна горко-хуморна нота се истакнува името на земјата Дискантрија, кое произлегува од избегнувањето на европските политичари да ја именуваат Македонија со нејзиното вистинско име, па го употребуваат изразот this country. Исто така, мошне впечатливи се и симболите на „зидот“ на јужната граница на Македонија, или на „возот“ (кој може да се доживее како далечно ехо на Ноевиот кораб) или, пак, неговото боење во црвена или сина боја, што алудира на партизацијата и поделеноста на народот. 
Специфично негување на богомилската традиција може да се препознае и во романот Вештица (2006) од Венко Андоновски, но во овој случај со поуниверзални димензии и во една покомплексна хибридна структура. Првенствено тоа е книга за праведните и еретиците и своевидно машко покајание за историската неправда кон жените запалени на клада и прогласени за вештерки, а во суштина е раскошна љубовна приказна со силна метафизичка потрага по смислата на постоењето. Главниот женски лик Јована, обвинета дека е вештица, е ќерка на богомилот и изведувач на сценски приказанија Исијан од Македонија. Богомилството е комплементарно со ереста на жените-вештици, а „...таа ерес, која почнува со мокрење врз распетието и откажувањето од Христос, продолжува со склучување договор со ѓаволот, кој од тие жени бара да го почитуваат како да е Бог“ (АНДОНОВСКИ 2006: 32). Казнувањето на жените од инквизицијата е прикажано во романот како лицемерна фрустрација на импотентни мажи и како сурова меѓуполова борба: „Ова е војна, рече. 'Ова е невидлива војна меѓу ќерките на Ева и синовите на Адам. Гревот на Каин не може ниту да се спореди со ова'...“ (АНДОНОВСКИ 2006: 360). А, всушност, романот над сѐ и пред сѐ е роман за љубовта, особено меѓу половите, исполнет со суптилни еротски пасажи и со прославување на женскоста.

Библиските алузии во овој роман произлегуваат од самата тематика и атмосфера и се пројавуваат во различни варијанти. Спомнувањата и повикувањата се честопати елементарни, како авторот намерно да го одржува низ дискурсот контактот со светите книги. На пример, тој пишува: „Во салата владееше совршен молк, како пред настанувањето на светот“ (АНДОНОВСКИ 2006: 45) или „Врнеше, истураше како да е почнат потоп“ (АНДОНОВСКИ 2006: 49); „Пливаш и рацете ти стануваат весла: весла на Ноев кораб, туќ тежок“ (АНДОНОВСКИ 2006: 194); „Еве: сомнежот и вербата се како издишување и вдишување. Не можеш да вдишуваш постојано, без да издишуваш'. Ненадејно, учителот го потчукна по рамото семинаристот и воодушевено рече: 'Имаме нов Соломон во Загреб!'“ (АНДОНОВСКИ 2006: 58).

И приказната на Вештица е двопланска и обединува две времиња: средновековие и современост, две љубовни приказни, две општествени ситуации. Романот е „отворена книга“ и текст во настанување кој се нуди за креативна доработка од страна на читателот. Овој роман повеќекратно ги применува и преиспитува лудистичките аспекти на постмодерната поетика. Таквите финеси се проблематика која заслужува многу поопширни и поопфатни препрочитувања. Што се однесува до проблематиката на библиските алузии, првенствено важно е што во овој роман обраќањето кон религиозноста се поставува во рамниште на метафизичко прераспрашување за тоа што е правда, што е вистина, да се верува ли или не, зошто страдаат невините, што е вина, смрт, љубов ... Главниот лик, отец Бенџамин, вака му се обраќа на Џордано Бруно (кој, 
патем, во романот се споменува како негов пријател): „Јас не се откажувам од уката твоја блескава: и јас и ти знаеме дека Бог е во Светото Писмо, но и во науката и броевите, како и во чистата квинта на псалмите што заедно ги слушавме за време на прошетките по плоштадот во Венеција, кога сфативме дека и музиката на божествените сфери може да се изрази со број!“ (АНДОНОВСКИ 2006: 120). Карактеристично за полифоничниот роман, и овој роман не поставува доминанти туку ги изложува различните опции и го поттикнува читателот да размислува за нив и да го пронајде стојалиштето од кое тој ќе ѝ пристапи на приказната. Низ целиот роман клатното се ниша меѓу верата и неверата, меѓу религијата и атеизмот, но непоколебливо се спротивставува на институциите на моќ, чиј највпечатлив израз е црквата: „Со векови црквата пресудува што е дозволено а што не, што е нормално, а што не, а никој, ама баш никој не ја знае дефиницијата за 'дозволено' и ’нормално““. (АНДОНОВСКИ 2006: 246)

Романот на Андоновски сугестивно уметнички вообличува духовна состојба карактеристична за современиот човек, која не се задоволува ниту со религијата, ниту со дефинитивниот атеизам, состојба која е еден вид пост-атеизам и пост-религија. Клишеата за објаснување на светот како да се веќе истрошени, недоволни, а поривот да се објаснува светот сепак тишти и не се смирува. Во таква состојба свртувањето кон кодот на Библијата нуди нови патишта за домислување. На пример, симболот на виножитото, божјиот завет, во романот на Андоновски се изедначува со Светото писмо: „Во тој миг огреа сонце. И се појави тоа: виножитото, истото она од утробата на рибата, сега преселено во утробата Божја: небесата. Гледаа во него, маѓосани од неговата убавина. 'Еве го Светото писмо', рече таа. 'Светото писмо од бои наместо од зборови сочинето. Вака, од бои сотворено, е покусо и појасно напишано’, додаде и замолче“ (АНДОНОВСКИ 2006: 329). Така Библијата од референца, станува метафора за сепостоечкиот свет, а светот се прифаќа како чудесна книга, книга на природата, на религијата, на науката...

Библиските алузии во постмодерен контекст имаат тенденција да ги десакрализираат библиските митови и да ги доближат до читателите неоспорните мудрости што тие ги еманираат. Опишувањето на ликот на Исус, и воопшто неговата визуелизација во сликарството или неговата замисла во книжевноста или филмот за религиозните претставува на некој начин оскврнување. Сепак, отсекогаш овој лик инспирирал и особено во современата книжевност наидува на голем број обработки. Од ренесансните платна преку Кнез Мишкин до супер-јунаците на популарната култура води една иста линија, така што поигрувањето на Андоновски со ликот на Зоро и ликот на Исус се покажува како навистина умесна споредба: „Зоро го немаше. Не сум го видел оттогаш. И ден денес се колебам: дали тоа беше Исус или Зоро? Зоро е црн, Исус е бел, ама убеден сум дека оној црниот таа ноќ ги имаше Неговите очи, истите оние 
очи што рамнодушно ме гледаа тоа попладне во црквата; истите тие очи кои сега велеа: правда има, само нема кој да слезе и да ви ја донесе. Погрижете се малку и сами. И до кога правдата на овој свет ќе ја делат херои под маска?“ (АНДОНОВСКИ 2006: 180). Андоновски им пристапува на библиските канони со блага иронија и хумор, така што и најригидните митови, како што е на пример оној за воскреснувањето, во неговиот роман се обликувани како една постмодерна весела травестија: „Исус ќе ги крене сите мртви, кога ќе дојде време за Воскресението’ Пораснав и денес знам дека постои сериозна можност тоа да се случи. Таа можност е информатичка, по откривањето на структурата на ДНК и компјутерите. Исус има компјутер и тоа бездруго ќе го стори, оти сите ние не сме ништо друго туку фајлови меморирани во неговиот компјутер, најнов модел на 'Пентиум' (Петокнижие се вика врвот на Светото писмо), Тоа значи дека ќе воскресне и нашето тело, како што е предвидено во христијанството: Исус е информатичар кој за секој од нас има свој фајл со сите подробности: висина, тежина, боја на очи, ментална структура, свест и потсвест, облик на дланка и колено...Смртта е само вирус кој ги јаде фајловите, но Исус има сигурно backup. Не е тој глупав: влезен е во ерата на информатиката и глобализацијата, сигурно“ (АНДОНОВСКИ 2006: 324) .

Романот на Андоновски, како и другите романи прикажани во овој труд, потврдуваат дека библиските мотиви не само што продолжуваат да живеат во културата на нашата современост, туку особено плодотворно се инкорпорираат во новите книжевни потраги, бидувајќи пре-испишани и про-толкувани на специфичен начин. Ослободени од строгата религиозна аура, тие се моќна духовна алатка во разгатнувањето, промислувањето и прифаќањето на животот и светот околу нас.

\section{Литература}

АНДОНОВСКИ В. (2007) Вештица. Скопје: Култура, 2007.

АНДОНОВСКИ В. (2010) Македонската фикција помеѓу богомилските импулси и теодицејата // Context/Контекст, 8. Скопје: Институт за македонска литература, 2010.

БАКОВСКА Е. (2008) На пат кон Дамаск (загубеното послание до Македонците). Скопје: Слово, 2008.

ГРАНДАКОВСКА С. (2009) Библиски мотиви во македонската книжевност // Мираж, 22, декември 2009.

ЃУРЧИНОВ М. (1996) Религиите и религиските аспекти на материјалната и духовната култура на почвата на Република Македонија, кн. 4. Скопје: МАНУ, 1996.

КОЦЕВСКИ Д. (2003) Роман за Ное (страв). Скопје: Слово, 2003.

МИХАЈЛОВСКИ Д. (2001) Пророкот од Дискантрија. Скопје: Каприкорнус, 2001. 
СВЕТО ПИСМО СТАРОГА И НОВОГА ЗАВЕТА (1956) Београд: Британско и инострано Библијско друштво, 1956.

CASANOVA P. (2004) The World Republic of Letters. Harvard University Press, 2004.

FRYE N. (1979) Anatomije kritike. Zagreb: Naprijed, 1979.

FRYE N. (1982) The Great Code: The Bible and Literature. New York: Harcourt Brace \& Company, 1982.

PINTARIĆ A. (2009) Biblija i književnost - interpretacije. Osijek: Sveučilište Josipa Jurja Strossmayera u Osijeku i Matica hrvastka Ogranak Osijek, 2009.

REPUBLIKA, broj 7-8, Zagreb: Drushtvo hrvatskih pisaca, (Tema broja: Biblijski poticaji u suvremenim europskim književnostima), 2011.

Biblical Allusions in Macedonian Contemporary Novel. This paper aims to show some models of biblical intertext in Macedonian contemporary novels. The concept "allusion" in this frames is not considered in classical sense, but it means more an inter-play, a ludicrous strategy of postmodern writing. The biblical allusions are interpreted as explicate quotes, implicit references, inclusions, re-writings, parodies, travesties, echoes etc. In the focus of interest are the novels: Novel for Noah by Danilo Kocevski, On the Road to Damascus by Elizabeta Bakovska, The Prophet of Diskantrija by Dragi Mihajlovski and Witch by Venko Andonovski.

Keywords: Bible, allusion, intertext, Macedonian contemporary novel 